\title{
Oral lichenoid lesions associated with amalgam restorations: report of two cases
}

\author{
Lesões liquenóides bucais associadas a restaurações de \\ amálgama: relatos de dois casos
}

\begin{abstract}
Purpose: Dental amalgam has been used as a dental restoration for more than 165 years. However, some patients with these restorations may present oral lichenoid lesions (OLL). OLL are chronic oral mucosal contact reactions to dental amalgam. Their diagnosis usually is based on the direct contact of the affected mucosa with the amalgam restorations, clinical appearance, and lack of migrations. A patch-test for mercury can be performed to confirm the diagnosis. Thus, the objective this work was to discuss the occurrence of this disease and your possibilities of existing differential diagnostic.

Case description: Two clinical cases were diagnosed as related to OLL. In both cases, the patients complained of a burning sensation in the oral mucosa adjacent to the amalgam restorations. The treatment involved replacing the amalgam restorations by composite. A complete remission of the painful symptoms was observed after 17 days in one case and after one month in the other, although the lesions in the oral mucosa did not disappear completely.
\end{abstract}

Conclusion: Dentists should be aware of OLL occurrence close to amalgam restorations and should be able to diagnose it and recommend the best treatment option.

Key words: Lichenoid eruptions; oral mucosa; permanent dental restoration; dental amalgam

\section{Resumo}

Objetivo: $O$ amálgama dentário tem servido como restaurador dentário a mais de 165 anos. Entretanto, alguns pacientes com estas restaurações têm demonstrado a ocorrência de lesões liquenóides orais (LLO). As LLO são reações de contato da mucosa oral crônicas ao amálgama dentário. Geralmente, o diagnóstico da lesão é feito pelo contato direto da mucosa afeta com a restauração de amalgama, pela aparência clínica, e a ausência de migrações. Um teste de contato para o mercúrio pode ser realizado para confirmar o diagnóstico. Assim, o objetivo deste trabalho foi discutir a ocorrência desta doença e suas possibilidades de diagnóstico diferencial existentes.

Descrição do caso: Dois casos clínicos foram diagnosticados como LLO. Em ambos os casos, os pacientes relataram sofrer de sensação de queimação na mucosa oral adjacente às restaurações de amálgama. Para ambos pacientes, os tratamentos envolveram a substituição das restaurações de amálgama. Completa remissão da sintomatologia dolorosa foi observada após 17 dias em um caso e após 30 dias em outro, embora as lesões na mucosa intrabucal não tenham desaparecido completamente.

Conclusão: Os cirurgiões-dentistas devem estar cientes da ocorrência da LLO relacionadas a restaurações de amálgama e devem saber como fazer o diagnóstico correto para assim recomendar a melhor forma de tratamento.

Palavras-chave: Erupções liquenóides; mucosa bucal; restauração dentária permanente; amálgama dentário

\author{
Marília Oliveira Barbosa a \\ Adriana Fernandes da Silva ${ }^{\circ}$ \\ Rodrigo Varella de Carvalho ${ }^{b}$ \\ Sandra Beatriz Chaves Tarquinio a \\ Flávio Fernando Demarco a
}

- School of Dentistry, Federal University of Pelotas, Pelotas, RS, Brazil.

bSchool of Dentistry, University of North Parana, Londrina, PR, Brazil

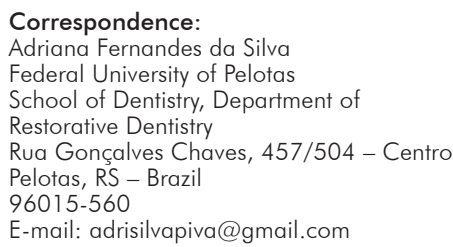

Received: April 21, 2011 Accepted: July 20, 2011

Conflict of Interest Statement: The authors state that there are no financial and personal conflicts of interest that could have inappropriately influenced their work.

Copyright: (C) 2011 Barbosa et al.; licensee EDIPUCRS. This is an Open Access article distributed under the terms of the Creative Commons AttributionNoncommercial-No Derivative Works 3.0 Unported License. 


\section{Introduction}

Dental amalgam has been used as a material for dental restoration for more than 165 years (1). However, some disadvantages of amalgam in comparison with adhesive composite restorations include problems with aesthetics; lack of adhesiveness, which requires removal of sound dental tissue to properly prepare the restoration cavity; and the potential toxicity of mercury for patients and the environment (1).

Dental amalgam is a metallic mass, which is formed by a mixture of liquid mercury and solid particles of a powder containing silver, copper, tin and zinc. Most of the toxic injuries are associated with the mercury content, and the dental literature has shown that amalgam restorations can be related to oral lichenoid lesions (OLL) (2). These OLL are frequently observed in the tongue, gingiva, and buccal mucosa that are in direct contact with amalgam restorations $(3,4)$, being classified in four types: lesions related to direct contact (OLLC), most commonly associated with amalgam restorations; lesions related to drugs (OLLD); lichenoid lesions in chronic graft versus host disease (cGVHD); and lesions associated with systemic diseases such as lupus erythematosus, the oral lichen planus $(2,5)$.

The clinical features associated with OLL may vary considerably, varying from white linear plaques, associated or not with erythema, to homogeneous white plaques, or ulcerations (2). In addition, more than one form can be present concurrently (1). In relation to their symptomatology, these lesions can range from subjective discomfort to severe pain. However, OLL do not migrate and involve only the oral mucosa directly in contact with dental amalgam restorations, which is a differential diagnosis from the true lichen planus (6).

It is well known that the direct contact with metals can induce several dermatoses, including hand dermatitis, palmoplantar pustulosis, and nummular dermatitis $(2,7)$. Thus, the replacing amalgam by another metal-free material is essential for definitive remission of the associated lesion (3). In the present paper, we report two cases of OLL caused by direct contact with amalgam restorations, which undergone clinical remission after the replacement of the amalgam by composite resin restoration.

\section{Description of two cases}

Both patients signed an informed consent form for dental treatment plan and publication of results.

\section{Case 1}

A 52-year-old female patient sought dental treatment at the School of Dentistry of the Federal University of Pelotas, Brazil. During the anamnesis, the patient complained of a burning sensation in her tongue. The clinical intraoral examination revealed a reddish and depapillated surface of her tongue in the areas with direct contact to the amalgam restoration, close to the mandibular first molar and second molar on the right side (Fig. 1). Besides this area, the patient presented overall good oral health conditions.
The mucosa lesion was diagnosed as an OLL due to its appearance and location. The treatment recommended to the patient was the immediate replacement of the amalgam restoration by a composite restoration in the mandibular first and second molars of the right side. Both diagnosis of the lesion and treatment plan was in accordance with further clinical consultation with an oral pathologist.

The composite resin restoration was performed following the standard clinical procedures and manufacturer's indications. After the amalgam removal and dental prophylaxis, a self-etching adhesive system and a siloranebased resin composite (Filtek P90, 3M ESPE, St Paul, MN, USA) were applied to restore the cavity. The restoration was finished and polished immediately.

After 17 days the patient returned to the dental school for control and she was no longer complaining about the burning sensation of her mouth, although a complete remission of the intraoral lesion was still not observed (Fig. 2).

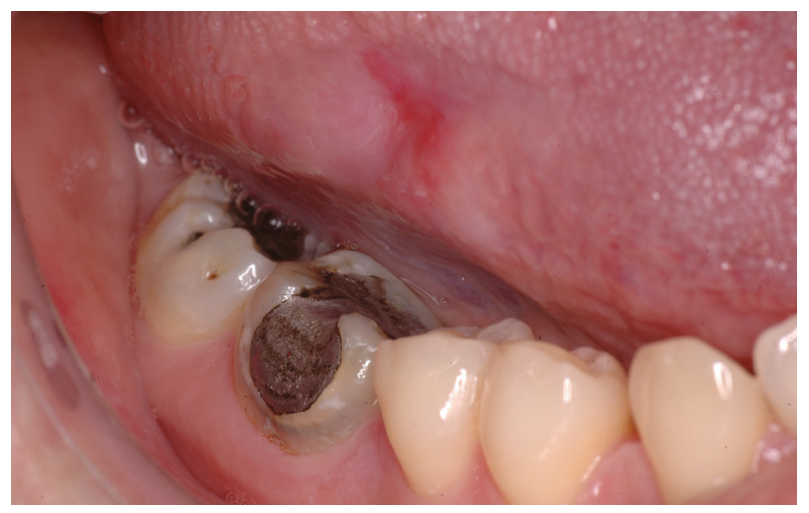

Fig. 1. A direct view of the reddish and depapillated sites in tongue in case 1 . Observe the amalgam restoration in direct contact with oral mucosa.

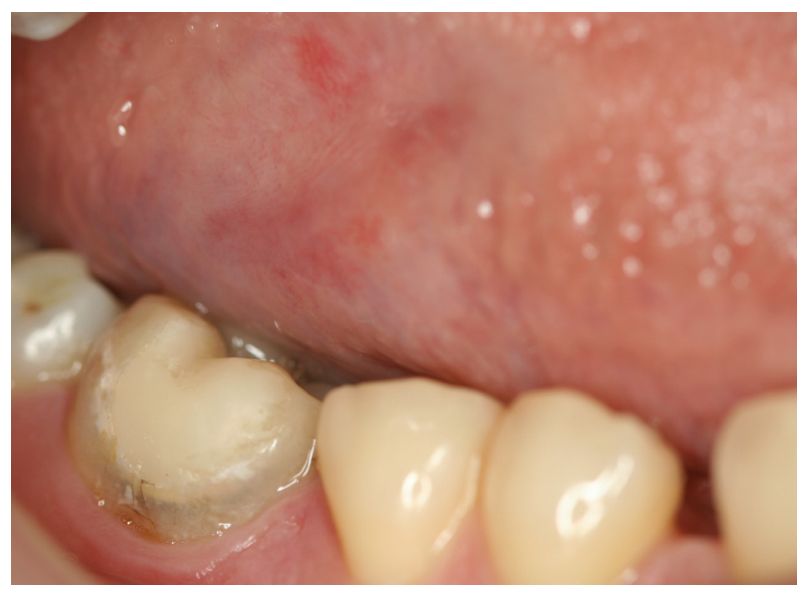

Fig. 2. A view of the lesion site 4 months after the replacement of the amalgam restoration by composite resin. There was a significant remission of the lesion, although it has not completely disappeared. The presence of reactional dentin can be observed around the restoration, which was maintained to preserve the dental structure. 


\section{Case 2}

A 76-year-old female patient was referred to the School of Dentistry at the Federal University of Pelotas (Brazil) complaining about a burning sensation in her oral mucosa. The intraoral clinical examination revealed an erythematous base with the presence of white striations adjacent to the amalgam restoration in the mandibular first premolar on the left side (Fig. 3). No systemic diseases were reported. Based on the clinical appearance and the proximity of amalgam restoration, an OLL was diagnosed and the replacement of the amalgam restoration by a composite restoration was planned.

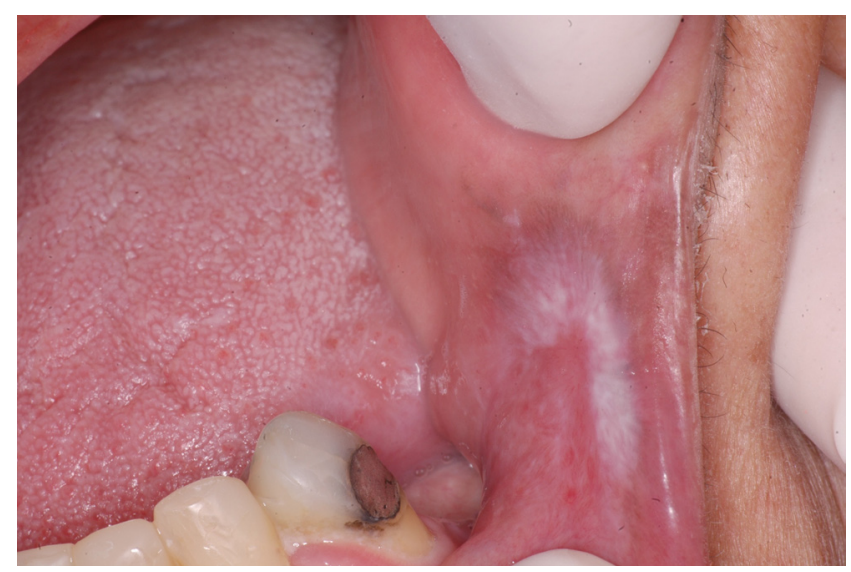

Fig. 3. Reddish region with presence of white striations adjacent to amalgam restoration in the left lower first pre-molar in the buccal mucosa of the second patient. It is also possible to observe light whitish plaques in the lateral border of tongue.

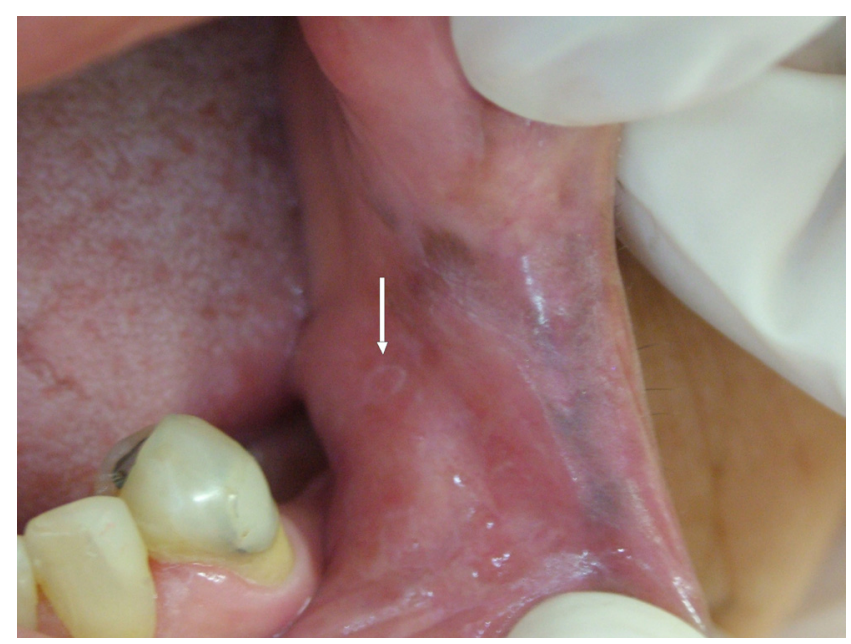

Fig. 4. Three months following amalgam replacement by composite resin, the partial remission of the lesions can be notice in buccal mucosa (arrow) and near of labial commissure. The presence of reactional dentin around the restoration can be observed, which was maintained to preserve the dental structure.
The restoration protocol followed the same steps of those performed for the case 1 previously reported. The only modification was the use of the total-etch adhesive technique and a microhybrid composite resin (Adper Scotchbond Multipurpose and Filtek Z250 TM, 3M ESPE, St Paul, MN, USA). Finishing and polishing procedures were performed immediately after completion of the composite restoration. After one month, the patient reported no burning sensation in her mouth. After three months, only slight white linear plaques were observed still persisting in the mucosa (Fig. 4).

\section{Discussion}

Although amalgam is the most used direct restorative material in dentistry (1), some amalgam compounds can promote adverse reactions in the oral cavity, such as OLL. These alterations seem to be caused by a contact allergy or Type IV hypersensitivity, which is an excessive manifestation of the immune response to an antigen (2) leading to tissue damage. Such reactions involve $\mathrm{T}$ lymphocytes that mediate hypersensitivity in response to a constituent of the amalgam restoration, commonly related to mercury as the allergen $(1,2)$; other components are rarely involved, such as copper, tin, or zinc.

The diagnosis of OLL relies on important aspects, such as the clinical appearance of the lesions, the lack of migration, and the association with adjacent amalgam restorations. The skin-patch testing is useful for identifying the allergen responsible for the hypersensitivity, but it needs to be performed by a specialist in dermatology or immunology (2). Rarely, when the final diagnosis is very difficult, the clinical evaluation by a multidisciplinary team may be necessary, including a specialist in immunology or dermatology, who will perform an epicutaneous test, a useful technique to confirm the Type IV hypersensitivity (8). Nevertheless, it is uncommon to have patients seeking for a dermatologist's appointment to diagnose and treat OLL, and the diagnosis often is established at the dental office, particularly in the cases de OLL by direct contact (2).

It is also relevant to differentiate OLL from OLP since both lesions can be very similar, being difficult to distinguish them clinically (4) and histopathologically $(2,6)$. However, OLLs are observed in intimate contact with the amalgam restorations, being more localized than OLPs. Besides, OLPs commonly have a bilateral presentation, more widespread and symmetrically distributed. Histologically, the connective tissue is characterized by the band-like lymphocytic inflammatory infiltrate and by the destruction of the basal keratinocytes. The cytotoxic action of the T-lymphocytes is responsible for the immune-mediated damage to the basal cells of the oral epithelium (9).

Finally, it is necessary to avoid direct contact between amalgam and the oral mucosa to achieve a complete and long-lasting treatment for OLL. Previous studies have demonstrated that the remission of the clinical signs vary from one to 24 months (10). In the present two clinical reports the amalgam restorations were replaced with 
composite resin, and a satisfactory remission of the OLL signals and symptoms was observed in both cases.

\section{Conclusion}

Both clinical cases underwent a healing process of the mucosa lesions after amalgam replacement by composite restoration in the teeth in contact with the lesions. Besides, the pain symptoms of the patients disappeared immediately after the replacement of those restorations. Although OLL-related conditions present low prevalence in the oral mucosa, they can cause significant discomfort for the patient. Therefore, dentists should be aware of their occurrence, diagnosis and treatment.

References 1. Bharti R, Wadhwani KK, Tikku AP, Chandra A. Dental amalgam: An update. J Conserv Dent 2010;13:204-8.

2. Cobos-Fuentes MJ, Martínez-Sahuquillo-Márquez A, Gallardo-Castillo I, Armas-Padrón JR, Moreno-Fernández A, Bullón-Fernández P. Oral lichenoid lesions related to contact with dental materials: a literature review.

3. Med Oral Patol Oral Cir Bucal 2009; 14:e514-20.

4. Grossman S, Garcia BG, Soares I, Monteiro L, Mesquita R. Amalgam-associated oral lichenoid reaction: case report and management. Gen Dent 2008;56:e9-11.

5. Fardal O, Johannessen AC, Morken T. Gingivo-mucosal and cutaneous reactions to amalgam fillings. J Clin Periodontol 2005;32:430-3.

6. van der Waal I. Oral lichen planus and oral lichenoid lesions; a critical appraisal with emphasis on the diagnostic aspects. Med Oral Patol Oral Cir Bucal 2009;14:310-4.

7. Eversole LR, Dam J, Ficarra G, Hwang CY. Leukocyte adhesion molecules in oral lichen planus: A t cell-mediated immunopathologic process. Oral Microbiol Immunol 1994;9:376-83.

8. Adachi A, Horikawa T, Takashima T, Ichihashi M. Mercury-induced nummular dermatitis. J Am Acad Dermatol 2000;43:383-5.

9. Nakayama H, Nogi N, Kasahara N, Matsuo S. Allergen control. An indispensable treatment for allergic contact dermatitis. Dermatol Clin 1990;8:197-204.

10. Al-Hashimi I, Schifter M, Lockhart PB, Wray D, Brennan M, Migliorati CA et al. Oral lichen planus and oral lichenoid lesions: Diagnostic and therapeutic considerations. Oral Surg Oral Med Oral Pathol Oral Radiol Endod 2007;103 Suppl:S25 e21-12.

11. Lind PO, Hurlen B, Lyberg T, Aas E. Amalgam-related oral lichenoid reaction. Scand J Dent Res 1986;94:448-51. 